\title{
Effect of Herbs and Herbal Products Feed Supplements on Growth in Fishes: A Review
}

\author{
Shubha Ratna Shakya \\ Department of Zoology, Tribhuvan University, Amrit Campus, Kathmandu, Nepal
}

\begin{abstract}
The herbs and herbal products added to the feed cure many diseases, promote growth, reduce stress, improve immunity and prevent infections in fish under culture. The addition of herbs and herbal products in fish diet is cheaper and environmental friendly with low side effect to the fish and consumers. Hence, their use as drugs in disease management in aquaculture is gaining popular. They are better than various antibiotics and vaccines used in the treatment of diseases. The present review highlights the importance of herbs and herbal products supplementation in fish feed for better fish production.
\end{abstract}

Keywords: Aquaculture, growth promoter, herb, fishes

${ }^{*}$ Corresponding author

Email: shubharatnashakya@gmail.com

\section{Introduction}

Fish of commercial importance are farmed in captivity under controlled conditions to fulfill the demand of white meat for human consumption. In commercial fish farming, the production is maximized by increasing the weight of individual fish [1, 2]. An artificial feed used in the aquaculture improves fish growth with maximum weight in short time [3]. New substances are added in fish feed to improve feed conversion efficiency that result in fish growth [4]. Many studies show that inclusion of herbs in fish diet has positive effect on growth and disease free fishes.

Excess use of various antibiotics, hormones and other synthetic drugs to control diseases and improve fish growth in aquaculture is the reason behind the emergence of drug resistant bacteria and production of toxic substances harmful to the environment and human health [5] and suppress immunity in the host [6]. Thus, their use has been criticized all over the world [7]. The herbs being cheaper, eco-friendly with minimum side effects are used as alternative to antibiotics in fish health management. World Health Organization (WHO) encourages supplemented diets incorporated with medicinal herbs or plants which minimizes the use of chemicals in fish diet [8]. In this context herbs and herbal products can be used in fish diet to increase feed consumption in fish under culture
[9]. Thus, this review is an informative collection in relation to fish growth through herbal feed supplements which may be useful for aqua farmers.

Bioactive compounds present in various plants are used in animal nutrition to stimulate feed intake, improve secretion of digestive enzyme and activate immune responses. These plants are also known to possess antibacterial, antiviral and antioxidant properties [10]. In aquaculture practices many herbs and herbal products are included in the fish diet to cure diseases, promote growth, reduce stress, stimulate appetite, boost immunity and prevent infections in producing healthy fishes [11- 15].

The flavor imparted by herbs and herbal products added in fish diet changed the eating patterns, increased feed consumption and stimulated digestion by increasing the secretion of saliva, various digestive enzymes, bile, pancreatic enzymes activity and mucus in fishes [16,17].

\section{Some herbal feed supplements used in Aquaculture}

Various herbs such as Hygrophila spinosa, Withania somnifera, Zingiber officinalis, Solanum trilobatum, Andrographis paniculata, Psoralea corylifolia, Eclipta erecta, Ocimum sacnctum, Picrorhiza kurooa, Phyllanthus niruri and Tinospora cordifoliaare used to reduce stress, increase immunity and control bacterial activities. Penaeus monodon in culture fed 
with diet containing these herbs improved growth [12]. Similarly, garlic, onion, marjoram, caraway, basil, anise, fennel, licorice, black seed and fenugreek are known to promote growth [13], feed conversion [15], improve protein digestibility and retain energy [18, 19] in aquatic animals. Promising results were achieved when Harada (1990) used garlic as stimulatory effect on olfaction instead of chemotherapeutics on Oriental weather loach (Misgurnus anguillicaudatus) and Japanese amberjack (Seriolaquin queradiata) [20]. This is similar with what was reported by Lee and Gao (2012) on Pelodiscus sinensis, Ctenopharyngodon idellus, Cyprinus carpio, Carassius auratus and Oreochromis niloticus [16]. Allicin is an active compound of garlic which induces increase in feed intake. Zeng (1996) also reported that adding 50 $\mathrm{mg} \mathrm{kg}-1$ of synthesized allicin to tilapia diet increased more than $2-3 \%$ of its weight gain after 45 days of culture [21]. The use of other culinary herbs such as red clover (Trifolium pratense), caraway (Carum carvi) and basil (Ocimum basilium) have shown positive results as growth promoting agents in Oreochromis niloticus [22]. Methanol extract of green tea (Camellia sinensis) enhanced the growth, survival rate, feed utilization and protein content in black rockfish (Sebastess chlegeli) [23]. Garlic supplemented diet improved weight gain (WG) and specific growth rate (SGR) in Orechromis niloticus [24]. Feed containing 3\% garlic powder improved WG, feed efficiency (FE), and SGR in Oreochromis niloticus [25]. In the same species high growth rate was observed in feeding diet with $2.5 \%$ garlic [26]. Garlic supplemented diet increased weight and SGR in tilapia [27]. Diet containing 3.2\% garlic powder showed best growth in Oreochromis niloticus [28]. Rainbow trout fed with $1.0 \%$ garlic diet increased growth and improved feed utilization [29]. Similarly, Oreochromis niloticus fed with garlic supplemented diets showed significant improvement in weight gain, feed conversion and protein efficiency [30]. Labeo rohita fed with herbal supplemented diet improved feed consumption resulting in better growth due to high protein synthesis [31].
Leaves of Sesbania grandiflora, Moringa oleifera, Coleus aromaticus, Ocimum basilium and Solanum verbascifolium have been found to promote growth in Oreochromis mossambicus [32]. O. mossambicus fed with diet containing Moringa oliefera showed maximum increased weight and specific growth rate. The maximum increase in length was observed in the fishes fed with Ocimum basilicum supplemented diet. Thus, plant ingredients are included in fish diet for their better growth. Red clover (Trifolium pretense) mixed with diet promoted growth in Oreochromis aureus [33]. Juvenile pike perch (Sander lucioperca) fed on diets supplemented with medicinal plants grew faster than those fed with the control diet [34]. In common carp Cyprinus carpio, guppy Poecilia reticulata, cichlid Cryptoheros nigrofasciatus, and red sea bream Pagrus major diet supplemented with medicinal plants improved growth. The use of Ginseng herb (Ginsana G115) in diet enhanced the growth in Oreochromis niloticus fingerlings [35-39]. The use of antibiotics can be replaced by optimized dose of Garlic to enhance growth performance and meat quality [40]. Metwally (2009) recommended supplementation of Garlic in fish feed to promote growth and increase survival rate [29]. The use of Phyllanthus emblica in any doses to feed of fish results in maximum growth [41]. John et al., (2007) used four different plants such as Eichinacea purpurea, Allium sativum, Nigella sativa, and Origanum marjoranaas feed additives which enhanced growth and improved survival of Oreochromis niloticus [42].

Various commercial herbal additives have been introduced in aquaculture for fish growth. Sangrovit ${ }^{\circledR} \quad$ (commercial product containing isoquinoline alkaloid sanguinarine) at low levels (25-100 $\mathrm{mg} \mathrm{kg}^{-1}$ ) in diet promoted growth in tilapia [43]. Tilapia fed with Sangrovit@ supplemented diets consumed more feed as compared to control and showed improved growth. In Catla catla, 5\% inclusion of Cynodon dactylonin diet improved the growth, feed efficiency, body composition, digestive enzyme and anti-protease activity [44]. The significant 
increase in SGR, feed conversion ratio (FCR) and $100 \%$ survival rate in the experimental groups were due to the presence of essential amino acids in Cynodon dactylon [45]. Catla catla fed with Cynodon dactylon incorporated diet showed the increased activity of digestive enzymes such as amylase and protease which enhanced digestion and absorption of nutrients essential for fish growth [44]. Inclusion of 5\% Ulva in the diet of Nile tilapia improved the growth, feed efficiency, nutrient utilization and body composition [46]. Oreochromis niloticus fingerlings fed with dietary herbal powder (Superliv ${ }^{\circledR}$ ) improved weight gain, FCR, protein efficiency ratio (PER) and SGR [47]. Bioflavonoids, plant chemicals with estrogenic activity, present in superliv ${ }^{\circledR}$ powder stimulated growth in common carp [48]. Sambhu and Jayaprakash (2000) recommended the use of $1 \%$ of Livol (IHF-1000) to enhance maximum growth and improve nutrient digestibility in prawn [49]. Livol (IHF-1000) is a purely herbal product containing different plant ingredients which improves digestion thereby leading to better growth in cultivable fishes [50, 51, 52]. The fish fed with different doses of ImmuPlus improved growth and inflammatory response (increase protease and amylase activity) [53]. The higher growth in treated fish is due to better utilization of feed through improved secretion of digestive enzymes and higher deposition of fats and protein in carcass [53].

Dietary administration of small quantities of vitamin $C$ is known to improve fish growth [54, 55, 56]. Chitosan and levamisole supplementation in diet of common carp enhanced its growth [57]. Ji et al., (2007) observed that the herbs promoted cellular lipid and fatty acid utilization and protein accumulation resulting in better growth performance in Pagrus major [38]. The dietary superliv ${ }^{\circledR}$ powder at different concentrations promoted growth of Oreochromis niloticus fingerlings [58]. The bioflavonoid compounds are present in superliv ${ }^{\circledR}$ powder which stimulated growth in common carp [48]. The use of fenugreek in Labeo rohita and Oreochromis mossambicus [59.
60], rosemary in Oreochromis niloticus [61, 62], thyme, rosemary and fenugreek in Oreochromis mossambicus [63] improved growth performance, disease resistance and immunity. The thyme diet improved growth and nutrient utilization in the European sea bass (Dicentrarchus labrax) [64]. It has been shown that herbs stimulated the secretion of pancreatic enzymes, important factors in nutrient digestion and assimilation [65]. The dietary addition of vitamin $C$ at the rate of $400 \mathrm{mg} \mathrm{kg}^{-1}$ increased average weight and specific growth rate of hybrid carp [66].

Vitamin $C$ fed fishes showed higher growth rate [67]. Pandey et al., (2012) showed use of Vitamin C and $\mathrm{E}$ as herbal drugs act as growth promoter and cure diseases of fishes and other aquatic animals [14]. Labh and Shakya (2016) studied the effect of lapsi (Choerospondias axillaries, Roxb.) fruit pulp in diet of Nile tilapia and common carp in the laboratory of Central Department of Zoology, Kathmandu. In the study $0.4 \mathrm{~g}$ ethanol lapsi fruit extract per $\mathrm{kg}$ is sufficient to enhance growth, survival, feed utilization and protein content of the body [68].

\section{Importance of Herbal feed supplements in Aquaculture}

Many factors such as density, water quality, feed quality and various environmental factors such as temperature, salinity and dissolved oxygen content of water play important role in increasing the meat quality and production in aquaculture. Besides the above mentioned factors disease outbreak, environmental conditions like rain, excessive temperature, floods, landslides, entry of predatory fish in the culture ponds or reservoirs, algal bloom etc. are also the cause of decreased aquaculture product. These factors cause stress and underutilization of normal feed leading to low feed conversion ratio. The antibiotics and synthetic drugs used to control diseases could damage the organs like liver and affect growth of fishes under culture leading to decreased productivity. To increase the economically viable production by solving the above problems, a 
proper herbal feed supplementation is required to take care of overall health of fishes and withstand the environmental challenges without affecting the growth survivability.

\section{Conclusion}

Many studies are being carried to study the effectiveness of herbal supplementation in fish feed to manage fish diseases and produce healthy fish. The outcomes of the studies suggest the use of herbs and herbal products feed supplements for healthy fishes in culture. Conclusively, the herbal feed supplements promote growth, minimizes stress, improves immunity and prevents various infections in fishes that will help to produce healthy fishes for human consumption.

\section{References}

1. Schuchardt D, Vergara JM, Palaciso HF, Kalinowski CT, Cruz $\mathrm{CMH}$, Izquierdo MS \& Robaina L: Effects of different dietary protein and lipid levels on growth, feed utilization and body composition of red porgy (Pagrus pagrus) fingerlings. Aqua Nutr. 2008 14(1): 1-9.

2. Verreth J: Growth and feeding metabolism in fish larvae. 1st international course on fish larvae nutrition. Wageningen Agricultural, Wageningen, The Natherland. 1991: 66-84.

3. Bhosale SV, Bhilave MP \& Nadaf SB: Formulation of Fish feed using Ingredients from Plant Sources. Res J Agric Sci. 2010 1:284-287.

4. Fernández-Navarro M, Peragón J, Esteban F, Higuera M \& Lupiáñez JA: Maslinic acid as a feed additive to stimulate growth and hepatic proteinturnover rates in rainbow trout (Onchorhynchus mykiss) Comp Biochem Physiol C Toxicol Pharmacol. 2006 144:130-140.

5. Esiobu N, Armenta L \& Ike J: Antibiotic resistance in soil and water environments. In J Environ Health Res. 2002 12:133-144.

6. Panigrahi A \& Azad IS: Microbial intervention for better fish health in aquaculture: the Indian scenario. Fish Physiol Biochem. 2007 33:429-40.

7. Baruah K, Norouzitallab P, Debnath D, Pal AK \& Sahu NP: Organic acids as non-antibiotic nutraceuticals in fish and prawn feed. Aquacult Health Internat. 2008 12: 4-6.

8. Dada AA: Improvement of Tilapia (Oreochromis niloticus, Linnaeus, 1758) Growth Performance Fed Three Commercial Feed Additives in Diets. J Aquac Res Development. 2015 6: 325.

9. Levic J, Sinisa M, Djuragic O \& Slavica S: Herbs and organic acids as an alternative for antibiotic growth promoters. Arch Zoot. 2008 11: 5-11.
10. Citarasu T: Herbal biomedicines: a new opportunity for aquaculture industry. Aquacult Int. 2010 18:403-414.

11. Citarasu T, Babu MM, Punitha SMJ, Venketa Ramalingam K \& Marian MP: Control of pathogenic bacteria using herbal biomedical products in the larva culture system of Penaeus monodon. International Conference on Advanced Technologies in Fisheries and Marine Sciences; Tirunelveli, India. M. S. University 2001104.

12. Citarasu T, Sekar RR, Babu MM \& Marian MP: Developing Artemia enriched herbal diet for producing quality larvae in Penaeus monodon (Fabricius). Asian Fish Sci. 2002 15:21-32.

13. Sivaram V, Babu MM, Immanuel G, Murugadass S, Citarasu T \& Marian MP: Growth and immune response of juvenile greasy groupers (Epinephelus tauvina) fed with herbal antibacterial active principle supplemented diets against Vibrio harveyi infections. Aquacult. 2004 237: 9-20.

14. Pandey G, Madhuri S \& Mandloi AK: Medicinal plants useful in fish diseases. Plant Arch. 2012 12(1): 1-4.

15. Shalaby SMM: Response of Nile tilapia, Oreochromis niloticus, fingerlings to diets supplemented with different levels of fenugreek seeds (Hulba). J Agric Mansoura Univ. 2004 29:2231-2242.

16. Lee JY \& Gao Y: Review of the application of garlic, Allium sativum, in aquaculture. J World Aquac Soc, 2012 43: 447-458.

17. Platel K, Rao A, Saraswah G \& Srinivasan K: Digestive stimulant action of three indian spice mixes in experimental rats. Die Nahrung. 2002 46: 394-398.

18. El-Dakar AY, Hassanien GDI, Gad SS \& Sakr SE: Use of medical and aromatic plants in fish diets: I. Effect of dried marjoram leaves on performance of hybrid tilapia Oreochromis niloticus $\times$ Oreochromis auraus, fingerlings. I Egypt Acad Soc Environ Dev (B Aquacult). 2004a 5:67-83.

19. El-Dakar AY, Hassanien GDI, Gad SS \& Sakr SE: Use of medical and aromatic plants in fish diets: 2. Effect of dried basil leaves on performance of hybrid tilapia Oreochromis niloticu $s \times$ Oreochromis auraus, fingerlings. 3rd Inter. Conf. on Animal Production and Health in Semi-Arid Areas, Suez Canal, Egypt: Suez Canal University 2004b 265-277.

20. Harada K: Attraction activities of spices for oriental weather fish and yellowtail. Bull Jap Soc Sci Fish. 1990 56; 2029-2033.

21. Zeng H, Ren ZL, \& Guo Q: Application of allicin in tilapia feed. China Feed. 1996 21: 29-30.

22. Ahmad $\mathrm{MH} \&$ Abdel-Tawwab M: The use of caraway seed meal as a feed additive in fish 
diets: Growth performance, feed utilization, and whole-body composition of Nile tilapia, (Oreochromis niloticus) (L.) fingerlings. Aquacult. 2011 314:110-114.

23. Hwang JH, Lee SW, Rha SJ, Yoon HS, Park ES, Han KH \& Kim SJ: Dietary green tea extract improves growth performance, body composition, and stress recovery in the juvenile black rockfish, Sebastes schlegeli. Aquacult Internat. 2013 21: 525-538.

24. Soltan MA \& El-Laithy SM: Effect of probiotics and some spices as feed additives on the performance and behaviour of the Nile tilapia, Oreochromis niloticus. Egypt J Aquat Biol Fish. 2008 12:63-80.

25. Shalaby AM, Khattab YA \& Abdel Rahman AM: Effects of garlic (Allium sativum) and chloramphenicol on growth performance, physiological parameters and survival of Nile tilapia (Oreochromis niloticus). J Venom Anim Toxins. 2006 12(2): 172-201.

26. Diab AS, El-Nagar GO \& Abd-El-Hady YM: Evaluation of Nigella sativa L (black seeds; baraka), Allium sativum (garlic) and BIOGEN as feed additives on growth performance and immunostimulants of $\mathrm{O}$. niloticus fingerlings. Suez Canal Vet Me. J. 2002 745-775.

27. Abou-Zeid SM: The Effect of Some Medical Plant on Reproductive and Productive Performance of Nile tilapia Fish. Ph.D. Thesis. Cairo University, Faculty of Agriculture; Cairo, Egypt. 2002.

28. Metwally MAA: Effects of Garlic (Allium sativum) on Some Antioxidant Activities in Tilapia Nilotica (Oreochromis niloticus). World J Fish Mar Sci. 2009 1(1): 56-64.

29. Nya EJ \& Austin B: Use of garlic, Allium sativum, to control Aeromonas hydrophila infection in rainbow trout, Oncorhynchus mykiss (Walbaum). J Fish Dis. 2009 32:963-970.

30. Abdel-Hakim NF, Lashin MME, Al-Azab AAM, \& Ashry AM: Effect of fresh or dried garlic as a natural feed supplement on growth performance and nutrients utilization of the Nile Tilapia (Oreochromis niloticas). Egypt J Aquat Biol Fish. 2010 14: 19-38.

31. Johnson C \& Banerji A: Influence of Extract Isolated from the Plant Sesuvium portulacastrum on Growth and Metabolism in Freshwater Teleost, Labeo rohita (Rohu). Fishery Tech. 200744 (2): 229-234.

32. Karpagam B \& Krishnaveni N: Effect of Supplementation of Selected Plant Leaves as Growth Promoters of Tilapia Fish (Oreochromis mossambicus). Res J Recent Sci. 2014 3:120-123.

33. Turan F: Improvement of growth performance in tilapia (Oreochromis aureus Linnaeus) by supplementation of red clover Trifolium pratense in diets. Israeli J Aquacult. 2006 58: 34-38.
34. Zakes Z, Kowalska A, Demska-Zakes K, Jeney G \& Jeney Z: Effect of two medicinal herbs (Astragalus radix and Lonicera japonica) on the growth performance and body composition of juvenile pike perch (Sander lucioperca). Aquacult. 2008 39:1149-1160.

35. Yilmaz E, Genc MA, Cek S, Mazlum Y \& Genc E: Effects of orally administered Ferula coskunii (Apiaceae) on growth, body composition and histology of common carp, Cyprinus carpio. J Anim Ve Adv. 2006 5: 1236-1238.

36. Cek S, Turan F \& Atik E: The effects of gokshura, Tribulus terrestris, on sex differentiation of guppy, Poecilia reticulata. Pak J Biol Sci. 2007a 10: 718-725.

37. Cek S, Turan F \&Atik E: Masculinization of convict cichlid (Chichlasoma nigrofasciatum) by immersion in Tribulus terrestris extract. Aquacult Internat. 2007b 15: 109-119.

38. Ji S, Takaoka O, Jeon G, Lee S, Ishumaru K, Seoka M \&Takii K: Dietary medicinal herbs improve growth and some non-specific immunity of red sea bream. Pagrus major. Fish Sci. 2007 73(1): 6369.

39. Ashraf MA and Goda, S: Effect of dietary Ginseng herb (Ginsana ${ }^{\circledR}$ G115) supplementation on growth, feed utilization, and hematological indices of Nile Tilapia, Oreochromis niloticus (L.), fingerlings. J World Aquac Soc. 2008 39(2):205-214.

40. Shakya SR \& Labh SN: Medicinal uses of garlic (Allium sativum) improve fish health and acts as an immunostimulant in aquaculture. European J biotechnol biosci. 2014 2(4): 44-47.

41. Sivagurunathan A, Innocent BX \& Muthulakshmi S: Immunomodulatory effect of dietary Nelumbo nucifera (lotus) in growth and haematology of Cirrhinus mrigala challenged with Pseudomonas aeruginosa. J Appl Pharm Sci. 2012 2: 191-195.

42. John G, Mesalhy S, Rezk M, El-Naggar G \& Fathi M: Effect of some immunostimulants as feed additives on the survival and growth performance of Nile tilapia, Oreochromis niloticusand their response to artificial infection. Egypt J Aquat Biol Fish. 2007 11(3): 1299 -1308.

43. Rawling MD, Merrifield DL \& Davies SJ: Preliminary assessment of dietary supplementation of Sangrovit ${ }^{\circledR}$ on red tilapia (Oreochromis niloticus) growth performance and health. Aquacult. 2009 294: 118-122.

44. Kaleeswaran B, Ilavenil S \& Ravikumar S: Growth Response, Feed Conversion Ratio and Antiprotease Activity of Cynodon dactylon (L.) Mixed Diet in Catla catla (Ham.). J Anim Vet Adv. 2011 10(4): 511-517.

45. Stewart WDP: Nitrogen Fixation. In: The Biology of Blue-Green Algae, Botanical Monographs, 
Carr NG and Whitton BA (Eds.) University of California Press, California 1973 9: 260-278.

46. Ergun S, Soyuturk M, Guroy B, Guroy D \& Merrifield D: Influence of Ulva meal on growth, feed utilization, and body composition of juvenile Nile tilapia (Oreochromis niloticus) at two levels of dietary lipid. Aquacult Int. 2009 17: 355-361.

47. Adekunle AD: Effects of herbal growth promoter feed additive in fish meal on the performance of Nile tilapia (Oreochromis niloticus(L.). Egypt Acad J Biolog Sci. 2012 4: 111-117.

48. Kocour M, Lynhard O, Gela D \& Rodina M: Growth performance of all- female and mixedsex common carp, Cyprinus carpio L. population in central European climatic conditions. J World Aquacult Soc. 2005 36: 103-113.

49. Shambhu C \& Jayaprakas V: Livol (IHF-1000), a new herbal growth promoter in white prawn, Penaeus indicus (Crustacea). Indian mar Sci. 2000 30: 38-43.

50. Shadakshari GS: Effect of bioboost forte, livol and amchemin $A Q$ on the growth and body composition of common carp, cyprinus carpio. M.Sc. thesis. University of Agricultural Science, Bangalore, India. 1993.

51. Unnikrishnan G: Effect of livol on growth and feed utilization and body composition of the Indian major carp, Catla catla. M.Sc. dissertation, University of Kerala, India. 1995.

52. Jayaprakash V \& Euphrassia CJ: Growth response of Indian major carp, Cirrhinus mrigala tolivol (IHF-1000)- a herbal product. Proc Indian National Sci Acad. 1997 63: 21-26.

53. Priyadarshini M, Manissery JK, Mohan CV \& Keshavanath P: Effect of ImmuPlus on Growth and Inflammatory Response to Fruend's Complete Adjuvant in Common Carp, Cyprinus carpio (L.). Turk J Fish Aquat Sci. 2012, 12: 291299.

54. Shobana KS: Modulatory effects of vitamin C on the disease resistance mechanism of Indian major carps. $\mathrm{PhD}$ thesis, University of Agricultural Sciences, Bangalore, India, 1997.

55. Misra CK, Das BK, Mukherjee SC \& Pradhan J: Effects of dietary vitamin $C$ on immunity, growth and survival of Indian major carp Labeo rohita, fingerlings. Aqua Nutr. 2007 13: 35-44.

56. Tewary A \& Patra BC: Use of vitamin $C$ as an immunostimulant. Effect on growth, nutritional quality and immune response of Labeo rohita (Ham). Fish Physiol Biochem. 2008 34: 251-259.

57. Gopalakannan A \& Arul V: Immunomodulatory effects of dietary intake of chitin, chitosan and levamisole on the immune system of Cyprinus carpio and control ofAeromonas hydrophila infection in ponds. Aquacult. 2006 255: 179-187.
58. Dada AA: Effect of herbal growth promoter feed additive in fish meal on the performance of Nile Tilapia, Oreochromis niloticus (L.). Egypt Acad J Biolog Sci. 2012 4:111-117.

59. Paul BN, Sarkar S, Mukhopadhyay PK \& Mohanty $\mathrm{SN}$ : Effect of dietary attractant on feed utilisation and growth of Rohu Labeo rohita (Ham.) fry. Anim Nutr Feed Techn. 2004 4(2): 145-152.

60. Mostafa AAZM, Ahmad MH, Mousallamy A \& Samir A: Effect of using dried fenugreek seeds as natural feed additives on growth performance, feed utilization, whole-body composition and entropathogenic Aeromonas hydrophilachallenge of monsex Nile Tilapia O. niloticus (L) fingerlings. Aust J Basic Appl Sci. 2009 3(2): 12341245.

61. Abutbul S, Golan-Goldhirsh A, Barazani O, Zilberg D: Use of Rosmarinus officinalis as a treatment against Streptococcus iniae in tilapia (Oreochromis sp.). Aquacult. 2004 238(1-4): 97-105.

62. Zilberg D, Tal A, Froyman N, Abutbu S, Dudai N \& Goldhirsh AG: Dried leaves of Rosmarinus officinalisas a treatment for Streptococcosis in tilapia. J Fish Dis. 2010 3(4): 361-369.

63. Ergün S, Yılmaz S \& Yigit M: Effects of thyme, rosemary and fenugreek on some hematological and immunological parameters of tilapia, Oreochromis mossambicus. In Mediterranean Aquaculture 2020, Aquaculture Europe, 2011 19-21; Rhodes-Greece, 2011 18-21.

64. Yılmaz S, Ergün S \& Türk N: Effects of herbal supplements on growth performance of sea bass (Dicentrarchus labrax): Change in body composition and some blood parameters. J BioSci Biotech. 2012 1(3): 217-222.

65. Frankic T, Voljc M, Salobir J \& Rezar V: Use of herbs and spices and their extracts in animal nutrition. Acta agriculturae Slovenica. 2009 94(2): 95-102.

66. Labh SN \& Chakrabarti R: Effects of different dietary supplements of vitamin c 1-ascorbate-2triphosphate calcium (latp-ca) on growth, tissue vitamin $\mathrm{c}$ and liver ultrastructure of Indian major carp mrigal Cirrhinus mrigala (H) during intensive aquaculture. J Theor Exp Biol. 2011 7: 195-201.

67. Lee KJ \& Dabrowski K: Interaction between vitamins $C$ and $E$ affects their tissue concentrations growth lipid oxidation and deficiency symptoms in yellow perch (Perca flavescens). Br J Nutr. 2003 89: 589-596.

68. Labh SN \& Shakya SR: Effects of dietary lapsi (Choerospondias axillaris Roxb.) on survival, growth and protein profile of common carp (Cyprinus carpio L) fingerlings. Int $j$ Zool Stud. 2016 1(5): 36-415. 